\title{
The Comparative Antimicrobial Effect of Activated Virgin Coconut Oil (AVCO) and Virgin Coconut Oil (VCO) against Dental Caries-Related Pathogens
}

\author{
Ummi Aqilah Haron \\ Department of Bioscience \\ Kulliyyah of Science \\ International Islamic University Malaysia \\ Kuantan, Malaysia \\ ummi.haron@gmail.com
}

\author{
Zurainie Abllah \\ Department of Paediatric, Orthodontic and Dental \\ Public Health \\ Kulliyyah of Dentistry \\ International Islamic University Malaysia \\ Kuantan, Malaysia \\ drzura@iium.edu.my
}

\author{
Nur Ainatul Mardia Mohamad Nasir \\ Department of Biotechnology \\ Kulliyyah of Science, International Islamic University Malaysia \\ Kuantan, Malaysia
}

\begin{abstract}
The present-day diet is astoundingly cariogenic, owing to the fact that high food intake with plenty of fermentable carbohydrates present in them. Classic regime against dental caries such as fluoride is often not able to cope with the resultant massive cariogenic challenge. Therefore, demands of alternatives for the classic regime in arresting issues related to oral health are always on the increase. In contemplation to improve and further develop novel antimicrobial compound, a great deal of research has gone into optimizing a lot of components presently available in natural sources which may help to contribute to the antimicrobial activity. The virgin coconut oil (VCO) is a case in point and has been the focus for decades as it has proven to possess antimicrobial features on Gram positive bacteria. Recently, there is a patterned Activated Virgin Coconut Oil (AVCO) that reported to have a broad antimicrobial spectrum. However, information regarding the inhibitory of AVCO and VCO against dental cariesrelated pathogens is yet to be established. In this study, we compared the antimicrobial effect of AVCO obtained from KL trading, Selangor, Malaysia, and VCO extracted in our laboratory. Their MIC and MBC against the selected dental caries-related pathogen; Streptococcus mutans, Lactobacillus casei and Candida albicans were determined. Out of the three tested organisms, L. casei was subjected to have a higher sensitivity towards AVCO (MIC: $0.78 \mathrm{mg} / \mathrm{ml}$ and MBC: $1.56 \mathrm{mg} / \mathrm{ml}$ ), followed by C. albicans (MIC: $3.12 \mathrm{mg} / \mathrm{ml}$ and MBC: $6.24 \mathrm{mg} / \mathrm{ml}$ ) and S. mutans (MIC: $6.24 \mathrm{mg} / \mathrm{ml}$ and MBC: $24.96 \mathrm{mg} / \mathrm{ml}$ ). In contrast to a positive finding of AVCO, VCO has shown no inhibitory effect on all tested dental caries-related pathogens. Furthermore, the time killing assay revealed that AVCO showed relatively quick-killing activity at the 8 hours of time for all tested organism. These finding correlates with that of AVCO possess bactericidal activity,
\end{abstract}

thereby allowing the possible classification of the AVCO as being a bactericidal agent.

Keywords-dental caries, activated virgin coconut oil (AVCO), virgin coconut oil (VCO), MIC, MBC

\section{INTRODUCTION}

Dental caries has been reported adding to the significantly high number of oral health problem worldwide. Pathological factors that normally associated with dental caries are acid producing bacteria that dwell in the oral cavity which possesses the ability to destruct the hard tissue portion of teeth by direct demineralization of the enamel of teeth [1]. For decades, Streptococcus mutans (S. mutans) and Lactobacillus casei (L. casei) were well-known by its acidogenic and acidophilic properties, more than other oral bacteria. While, S. mutans have been shown to play a vital part in the initiation of dental caries since its activities lead to colonization of the tooth surface, oral biofilm formation and demineralization of tooth enamel, L. casei have been suspected to be secondary invaders that contribute to the progression of lesions $[1,2]$. Besides that, in the case of neglected caries lesion, the opportunistic organism will eventually take place and cause further progression of dental caries. A common condition associated with the opportunistic organism in the oral cavity is oral candidiasis. A condition that is the result of from the infection of the oral cavity caused by Candida species where the common Candida species isolate of the oral cavity is Candida albicans (C. albicans). Both opportunistic and pathogenic microbes reside in the mouth affect the teeth, causing dental caries, and contribute various of disease complications [3]. These 
complications caused by the oral pathogens are what has made the effort to combat dental caries challenging.

For decades, fluoride had been widely used as a regime to combat early stage of dental caries where it works primarily via topical mechanisms which inhibits demineralization of the tooth, enhance remineralization of the tooth and inhibits bacterial enzymes productions [4]. Conceding the fact that fluoride has the ability to inhibit demineralization and plaque bacteria, the major role of fluoride is still limited to the enhancement of remineralization, thereby, sole use of fluoride as an option for treatment is unrealistic [5]. For the case of the late stage of dental caries, mechanical removal of teeth is adapted to control the spreading of oral pathogens infections. While initial and mid stages of dental caries treatment option remain to be the administration of antibiotics, a recent report has shown that cariogenic $S$. mutans and $\mathrm{C}$. albicans showed a gradual increase in resistant pattern to antibiotics and antifungal [6]. Noticeably, available treatment for dental caries certainly have their own limitations, including side effects, total loss of tooth and the development of resistance. There is, therefore, an urgent need of a novel treatment for the oral cariogenic bacterial infections.

Historically, coconut oil, extracted from coconut palm tree (Cocos nucifera) has been stapled in the diets of those who live in the tropical region [7]. Prominent and recent studies have shown that unrefined coconut oil, Virgin Coconut oil (VCO) can be exceptionally advantageous, as it possessed antimicrobial characteristic towards a broad range of species, ranging from Mycobacterium species, Gram-positive and Gramnegative bacteria $[8,9]$. Differ from other common oils which are usually composed of long chain fatty acids, coconut oil and VCO are concentrated with short and medium chain fatty acids, and therefore classified as medium chain fatty acids (MCFA) [9]. Eastern scholars had outlined that, of the fatty acids present in coconut oil, lauric acid ( $\mathrm{C}: 12: 0)$ is proven to be more active as antibacterial agent compared to caprylic acid (C8:0), capric acid (C10:0), and myristic acid (C14:0) [11].

Recently, there is a patterned Activated Virgin Coconut oil (AVCO) which were reported to have an effective amount of medium-chain free fatty acids (caprylic, capric and lauric acid) and their corresponding derivatives (monocaprylin, monocaprin, and monolaurin) [12]. The AVCO was reported to have great antimicrobial effect against a wide spectrum of microbes ranging from Gram Negative, Gram-Positive and even fungal species suggesting beneficial application of AVCO as a potential oral health aid.

Therefore, the current study aims to assess and compare the antibacterial activity of AVCO and VCO in vitro against dental caries-associated pathogens. AVCO has been reported to kill Mycobacterium species faster than some Gram-positive bacteria, thereby to determine the optimum time for AVCO against dental cariesassociated pathogens, a time-kill study was also conducted throughout the study.

\section{MATERIALS AND METHODS}

\section{A. Bacterial strains and culture conditions}

The oral pathogens tested in this study were, Streptococcus mutans ATCC 25175, Lactobacillus casei ATCC 334 and Candida albicans ATCC 4901. All strains were procured from American type culture collection (ATCC), USA.

S. mutans were cultured in Brain heart infusion broth (BHIB) (CM1135, Thermo Scientific ${ }^{\mathrm{TM}}$ Oxoid $^{\mathrm{TM}}$, MD, USA) and on BHI agar. L. casei were culture on De Man Rogosa Sharpe (MRS) agar (CM0361, Thermo Scientific $^{\mathrm{TM}}$ Oxoid $^{\mathrm{TM}}$, MD, USA) and were grown in MRS broth (MRSB). While, C. albicans was cultured on Yeast-extract Peptone Dextrose (YPD) (CM01125, Thermo Scientific ${ }^{\mathrm{TM}}$ Oxoid ${ }^{\mathrm{TM}}$, MD, USA) and grown in YPD broth.

All organisms were maintained in an aerobic condition and incubated at $37^{\circ} \mathrm{C}$ for 24 hours prior to the test. The cultures of bacteria were maintained in their appropriate agar slants at $4^{\circ} \mathrm{C}$ throughout the study and used as stock cultures.

\section{B. Preparation of $\mathrm{VCO}$}

All coconuts (cocos nucifera) fruits used in the study were obtained from Taman Agrotechnology MARDI Cherating. The oil extraction process was performed according to the method described by Fife [13]. The meat of mature brown coconuts was blended with the blender until it is well shredded. The coconut milk was filtered using cheesecloth over a wide-mouth jar and the process was repeated and the coconut milk was gathered into a jar. The coconut milk then was rested for more than 24 hours. As it sets, the coconut milk and oil were separated and a layer of curd appeared at the top of the jar. The curd was scooped out and the pure VCO is left in the jar and store in dark glass bottle at room temperature until needed to be used.

\section{AVCO and VCO stock preparations}

In the present study, the AVCO product was obtained from KL Best Trading (Selangor, Malaysia) and VCO was prepared in our laboratory following the method by Fife [13].

An initial stocks solution of AVCO and VCO were prepared by dissolving $100 \mathrm{mg}$ of the oils with one $\mathrm{ml}$ of the $0.1 \%$ Tween 80 . The stocks solution were stored at the maximum time at 6 hours prior to the test.

\section{AVCO and VCO sterility test}

Sterility test for AVCO and VCO were cultured on chocolate and MacConkey's agar plates and incubated overnight at $37^{\circ} \mathrm{C}$, the MacConkey's agar aerobically and the chocolate agar in a candle extinction jar. This was done to ensure that the AVCO and VCO were completely sterile. All media prepared were picked at random and incubated overnight at $37^{\circ} \mathrm{C}$ for the same purpose. 


\section{E. Antibacterial activity assays}

Paper disc diffusion method to screen the efficacy of AVCO and VCO against the S. mutans, L. casei and C. albicans strains were performed as a preliminary step in the current study. The AVCO and VCO stock was diluted with $0.1 \%$ Tween 80 at the following concentration 25 and $200 \mathrm{mg} / \mathrm{ml}$ respectively. A volume of $20 \mu \mathrm{L}$ of each concentration was, respectively, infused into the paper disc with $6 \mathrm{~mm}$ diameter (Oxoid, Badhoevedorp, Netherlands), and then placed onto Mueller-Hinton agar (MHA) plates (CM1135, Thermo Scientific $^{\mathrm{TM}}$ Oxoid $^{\mathrm{TM}}$, MD, USA), which were previously inoculated on the surface agar with $200 \mu \mathrm{L}$ of $10^{5} \mathrm{cfu} / \mathrm{mL}$ suspension for each tested bacterium.

$0.1 \%$ Tween 80 was used as a control and three standard reference antibiotics, Chlorhexidine (20 $\mathrm{mg} /$ disk and Nystatin (20 mg/disk), were used as reference controls for the tested bacteria. The plates were then incubated at $37^{\circ} \mathrm{C}$ for $24 \mathrm{~h}$ for all bacterium. The antibacterial activity was evaluated by measuring the diameter of inhibitory zones in millimeters and the means were expressed as the results of three determinations.

\section{F. Minimum inhibitory concentration (MIC) of AVCO and $V C O$}

The MIC of the AVCO and VCO required to inhibit bacterial growth was determined using the microbroth dilution method, as proposed by Mith et al. with some modifications [14]. A $100 \mu \mathrm{l}$ of $100 \mathrm{mg} / \mathrm{ml}$ AVCO dissolved in $0.1 \%$ Tween 80 and incorporated into the wells containing $\mathrm{MH}$ broth medium to obtain a final concentration from 0 to $0.1 \%(\mathrm{v} / \mathrm{v})$ was added to the first row of the 96-well plate and a serially diluted by double technique to achieve $49.92,24.96,12.48,6.24,3.12$, $1.56,0.78$ and $0.39 \mathrm{mg} / \mathrm{ml}$, respectively. The bacteria strains were grown overnight (1 colony of the bacteria was picked and grown in MH broth for bacteria and YPD broth for yeast). The bacterium cells suspensions, at $A_{510}$, for $S$. mutans $A_{340}$ for $L$. casei and $A_{450}$ for $C$. albicans of 0.1 were diluted 10 -fold and $100 \mu$ l of the suspensions were dispensed into each well.

Appropriate cell controls, Tween 80 controls, and media controls were also set up and the plate was incubated at $37^{\circ} \mathrm{C}$ overnight. Bacteria cells from an overnight culture were added to the Tween 80 controls wells to ensure that no inhibition was caused by the addition of Tween 80. All test were performed in triplicates. The plates were assessed visually and the optical density was measured at the wavelengths of 510, 340 and $450 \mathrm{~nm}$ respectively.

The MIC was determined to be the lowest concentration of AVCO and VCO which produced an optical density of $\leqslant 25 \%$ than that of the cell control, or the lowest concentration of AVCO with no visible cell growth (as seen by the turbidity).

\section{G. Minimum bactericidal concentration (MBC) of} AVCO and VCO

Next, we adapted the methodology with some modification from Koh and Long's [15] to determine the MBC value of AVCO and VCO. The bactericidal assay conducted to assess the bactericidal activities of both AVCO and VCO through microbroth dilution. The $\mathrm{MBC}$ is identified by determining the lowest concentration of AVCO and VCO that reduces the viability of the initial bacterial inoculum by $\geqslant 99.9 \%$. Culture fluids $(10 \mu \mathrm{L})$ from MIC wells showing no visual signs of turbidity were transferred on a Mueller Hinton agar and incubated at $37^{\circ} \mathrm{C}(24 \mathrm{~h})$. The lowest concentration of the antimicrobial that will prevent the growth of an organism after subculture onto Mueller Hinton agar was recorded as the MBC. The MBC values for each bacteria strain were confirmed viable count method. Panels of respective antibiotics served as positive controls for the study.

\section{H. Effect of AVCO against oral pathogens: Time kill study \\ For the time kill study, two different concentration of} AVCO (MIC and MBC) were used to determine the optimum time for inhibiting the growth of ATCC's oral pathogens strains, which were $7.81 \mathrm{mg} / \mathrm{ml}$ and 31.25 $\mathrm{mg} / \mathrm{ml}$ for $\mathrm{S}$. mutans, $0.78 \mathrm{mg} / \mathrm{ml}$ and $1.78 \mathrm{mg} / \mathrm{ml}$ for $\mathrm{L}$. casei and $3.13 \mathrm{mg} / \mathrm{ml}$ and $6.25 \mathrm{mg} / \mathrm{ml}$ for C. albicans.

Freshly prepared sterile specified broth medium was inoculated with fresh culture (approx. $1 \times 10^{5}$ cells) of each dental caries-related pathogen in different tubes. Each cells were exposed to the two-different concentration of AVCO (MIC and MBC) separately. All the test tubes were incubated at $37^{\circ} \mathrm{C}$ and $160 \mathrm{rpm}$. At predetermined time points $(0,4,8,12,16,20$ and 24 hours after incubation with agitation at $37^{\circ} \mathrm{C}$ ), a $100-\mu \mathrm{L}$ aliquot was removed from every solution and appropriately diluted $\left(10^{-1}\right.$ to $\left.10^{-7}\right)$ in $900-\mu \mathrm{L}$ sterile water.

A $100-\mu 1$ aliquot from each dilution was spread on the specified agar plate. Colony counts were determined after incubation at $37^{\circ} \mathrm{C}$ for $24 \mathrm{~h}$. Time-kill curve was determined by plotting mean colony count data $(\log 10$ $\mathrm{CFU} / \mathrm{mL}$ ) as a function of time for each isolate.

\section{RESULTS}

A disc diffusion test was carried out in the current study using AVCO and VCO. The test act as a preliminary screening to evaluate the sensitivity of the selected oral pathogens towards AVCO and VCO.

If the selected pathogens were unable to grow after the incorporation of the disc with AVCO or VCO, it eventually indicates that the organisms might be sensitive towards them. For example, the inhibition zone presence on all tested oral pathogens after incorporated with $\operatorname{AVCO}(25 \mathrm{mg} / \mathrm{ml})$ disc, while there is no inhibition zone presence on inoculation of $\mathrm{S}$. mutans and L. casei after incorporated with VCO $(200 \mathrm{~m} / \mathrm{ml})$ disc (Figure 1) might indicate that all tested oral pathogens are more sensitive towards AVCO instead of VCO. 

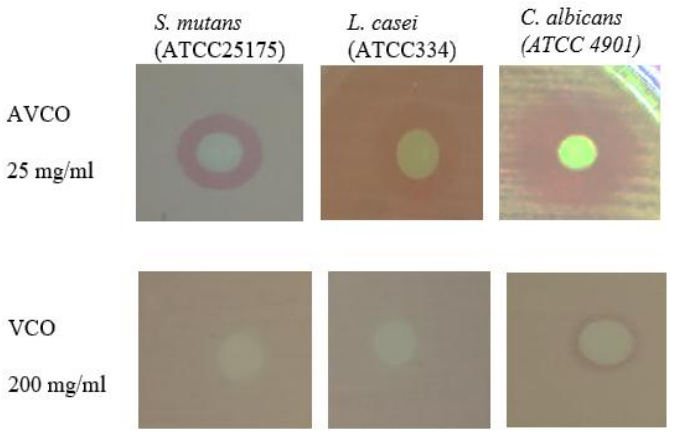

Figure 1. Diffusion discs incorporated on $\mathrm{MH}$ agar plate for tested oral pathogens after a 24-h incubation period. Inhibition activity of AVCO $(25 \mathrm{mg} / \mathrm{ml})$ and VCO $(200 \mathrm{mg} / \mathrm{ml})$ on selected oral pathogens. Inhibition zones suggest successful inhibition of the oil to the selected pathogens growth.

TABLE I. AVCO AND VCO DISK DIFFUSION SENSITIVITY TEST

\begin{tabular}{|c|c|c|c|c|c|}
\hline \multirow[b]{2}{*}{$\begin{array}{l}\text { Microbial } \\
\text { Strains }\end{array}$} & \multicolumn{5}{|c|}{ Mean Diameter $(\mathrm{mm}) \pm \mathrm{SE}$} \\
\hline & $\begin{array}{c}\text { CHX } \\
20 \\
\mathrm{mg} / \mathrm{ml}\end{array}$ & $\begin{array}{c}\text { Nystatin } \\
20 \\
\mathrm{mg} / \mathrm{ml} \\
\end{array}$ & $\begin{array}{c}\text { VCO } \\
200 \mathrm{mg} / \\
\mathrm{ml}\end{array}$ & $\begin{array}{c}\text { AVCO } \\
25 \mathrm{mg} / \\
\mathrm{ml}\end{array}$ & $\begin{array}{c}\text { P- } \\
\text { value }\end{array}$ \\
\hline $\begin{array}{l}\text { S. mutans } \\
(\text { ATCC25175) }\end{array}$ & $12 \pm 0.0$ & NA & ND & $8 \pm 0.0$ & \multirow{3}{*}{$<0.001$} \\
\hline $\begin{array}{l}\text { L. casei } \\
\text { (ATCC334) }\end{array}$ & $\begin{array}{c}18.77 \pm \\
0.88 \\
\end{array}$ & NA & ND & $\begin{array}{c}7.7 \pm 0.3 \\
3 \\
\end{array}$ & \\
\hline $\begin{array}{l}\text { C. albicans } \\
\text { (ATCC4901) }\end{array}$ & NA & $17 \pm 0.57$ & $3 \pm 0.3$ & $\begin{array}{c}14.77 \pm \\
0.33 \\
\end{array}$ & \\
\hline
\end{tabular}

It can be seen from the data in Table 1, for disk diffusion test showed that all tested oral pathogens were significantly sensitive to AVCO and resistance towards VCO, where statistically p-value is less than 0.001 (Table 1). However, there is a vaguely small inhibition zone found on $\mathrm{C}$. albicans inoculum after incorporated with VCO $(200 \mathrm{mg} / \mathrm{ml})$ disc. Panels of antibiotic used in the test serve as positive controls and blank discs were used as negative controls.

After obtaining a preliminary data, the MIC and MBC test were carried out to determine the optimum concentration of the oils to completely inhibit the growth of bacteria cell. While the bacterial cell controls, with no oil treatment, showed no growth inhibitory effect, the oils and medium controls were clear, with no contamination involved.

\section{TABLE II. THE MIC AND MBC/MFC OF AVCO AND VCO}

\begin{tabular}{|c|c|c|c|c|}
\hline \multirow{2}{*}{$\begin{array}{c}\text { Microbial } \\
\text { Strains }\end{array}$} & \multicolumn{4}{|c|}{ MIC (mg/ml) } \\
\hline & Activity & VCO & AVCo & P-value \\
\hline \multirow{3}{*}{$\begin{array}{l}\text { S. mutans } \\
\text { (ATCC25175) }\end{array}$} & MIC & ND & 6.24 & $<0.001$ \\
\hline & MBC & ND & 24.96 & \\
\hline & $\mathrm{MIC} / \mathrm{MBC}$ & ND & 0.25 & \\
\hline \multirow{3}{*}{$\begin{array}{l}\text { L. casei } \\
\text { (ATCC334) }\end{array}$} & MIC & ND & 0.78 & \\
\hline & MBC & ND & 1.56 & \\
\hline & $\mathrm{MIC} / \mathrm{MBC}$ & ND & 0.43 & \\
\hline \multirow{3}{*}{$\begin{array}{l}\text { C. albicans } \\
\text { (ATCC4901) }\end{array}$} & MIC & ND & 3.12 & \\
\hline & MFC & ND & 6.24 & \\
\hline & $\mathrm{MIC} / \mathrm{MFC}$ & ND & 0.5 & \\
\hline
\end{tabular}

As shown from Table II, out of three tested oral pathogens, L. casei was found to be highly sensitive towards AVCO with mean MIC and MBC value of 0.78 $\mathrm{mg} / \mathrm{ml}$ and $1.56 \mathrm{mg} / \mathrm{ml}$ followed by C. albicans with mean MIC and MBC of $3.12 \mathrm{mg} / \mathrm{ml}$ and 6.24 and S. mutans, mean MIC and MBC values of $6.24 \mathrm{mg} / \mathrm{ml}$ and $24.96 \mathrm{mg} / \mathrm{ml}$ respectively. Overall, VCO showed no effect in the inhibition of any tested organisms. From the result obtained, it is determined that all selected oral pathogens are significantly sensitive towards AVCO as compared to the $\mathrm{VCO}$ where the statistical p-value is less than 0.001 .

From the results obtained from disc diffusion test and $\mathrm{MIC} / \mathrm{MBC}$ test, it is clearly shown that VCO has no antimicrobial effect towards the selected oral pathogens. Therefore, we precede the test with only AVCO to determine the time-killing effect.
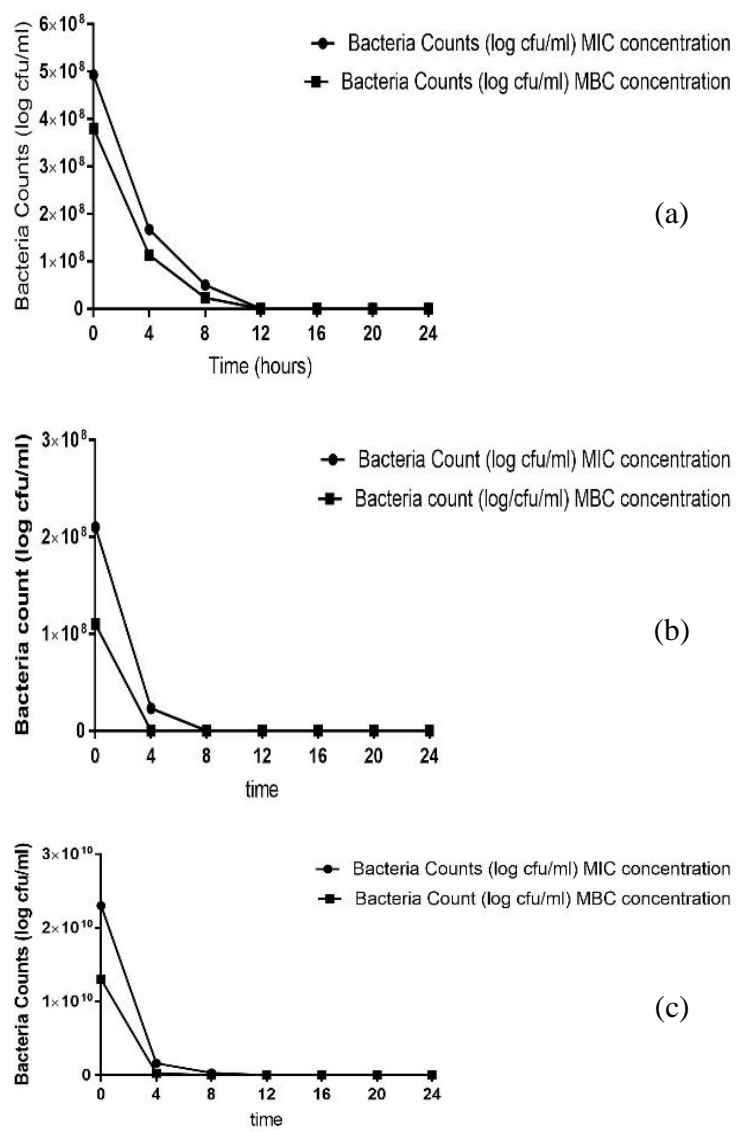

Figure 2. Time-kill curve of (a) denotes S. mutans counts in the presence of MIC and MBC concentrations and (b) denotes L. casei counts in the presence of MBC concentrations and (c) denotes C. albicans counts in the presence of MIC and MBC concentrations. The outcomes were carried out in triplicates and data were expressed as means \pm standard error (SEM).

In the current study, it is found that AVCO successfully killed all the tested dental caries-related pathogen after 8 hours point in time (Figure 2). Two concentrations (MIC and MBC) of AVCO against respective oral pathogens were used in this study. Inclusively, L. casei and C. albicans were found to be inhibited easily using MBC concentration of AVCO. 
While the inhibition of $\mathrm{S}$. mutans requires more time as compared to the other tested oral pathogens.

\section{DISCUSSION}

Novel antimicrobial agent utilizing natural product has surged in popularity, particularly during the postantibiotic era where antibiotic resistance has become a frequent issue. Prominent and recent scholars have shown that the medium chain fatty acids that are abundant in virgin coconut oil possess a very promising antimicrobial activity against a relatively broad spectrum of microbes. In the current study, disc diffusion test was used to screening antimicrobial effect of AVCO and $\mathrm{VCO}$, followed by broth dilution method to determine and compare the MIC and MBC for both AVCO and VCO. Other than that, the time-killing assay also has been performed in the study to evaluate the bactericidal activity of the AVCO in a concentration-dependent manner. Using both concentrations of MIC and MBC, the optimal concentration required to attain and sustain $>99.99 \%$ of killing, up to 24 hours, were determined. At different time intervals, the number of viable cells left was measured and the dose-dependent bactericidal activity of the AVCO, determined. It is crucial to establish an assay before being able to use novel antimicrobial agents in clinical settings to test the sensitivity of pathogens. It is therefore of utmost importance to determine their concentrations and the MIC/MBC assay carried out appears to be reproducible and reliable

The MIC and MBC value of AVCO and VCO in the current study were determined by the microbroth dilution method. A significant difference was determined between the AVCO treated and VCO treated cell suspensions. In the case of AVCO, MIC of $6.24 \mathrm{mg} / \mathrm{ml}$ and $\mathrm{MBC}$ value of 24.96 was observed to inhibit the growth of the $\mathrm{S}$. mutans. However, a lower MIC of $0.78 \mathrm{mg} / \mathrm{ml}, 3.12 \mathrm{mg} / \mathrm{ml}$ and $1.56 \mathrm{mg} / \mathrm{ml}, 6.24$ $\mathrm{mg} / \mathrm{ml}$ for MBC was observed with AVCO against the L. casei and C. albicans strains. The fact that activated VCO has undergone treatment with enzymes that activates the breakdown process of fatty acids that play a crucial role in the antimicrobial activity, might be one of the reasons why AVCO has such a good antimicrobial effect. The current finding is in agreement with another research that found that enzyme-modified coconut oil strongly inhibited the growth of most strains of Streptococcus bacteria, including S. mutans [16].

Interestingly, all the selected dental caries-related pathogens are not sensitive towards VCO. The current finding is in conflict with a recent finding that reports the sensitivity of $\mathrm{S}$. mutans inoculum after incorporated with VCO. The reason that can justify such contradiction is might be due to the fatty acids contents in the VCO. It is reported that content of active compound present in the plant might vary according to the geographical area that includes soil content and seasonal variations [9]. Since the coconut used in this project are collected from a local farm in Malaysia, and the VCO used in the contradict claims were from India, the geographical difference might have influence in the active compound of VCO which in this case, the fatty acids to be different. However, a more recent study has reported that periodontal pathogens are resistant towards VCO [18]. Even though the finding is a preliminary report, it does support our current finding and might suggest that possible of resistance organisms towards VCO.

In the final part of the current study, a time-killing assay was performed only for AVCO to determine the viability of the organism after in contact with the oil after a specific time. The results of the time-kill studies show the L. casei was rapidly killed by AVCO followed by $\mathrm{C}$. albicans and $\mathrm{S}$. mutans. The fact that $\mathrm{S}$. mutans was killed slower as compare to the other two pathogens might be support by the MIC and MBC finding, where it requires slightly higher concentration of $\mathrm{AVCO}$ in order to achieve total inhibition. A study done by Koh and Long's has shown that AVCO able to kill mastitis related pathogens with very low concentration at a shorter period of time, thereby, supporting the current finding $[12,15]$.

The findings of this study will add up to the currently available knowledge of the effectiveness of AVCO in the context of the ability to inhibit bacterial cell growth. This may draw more in-depth discovery to whether AVCO can be used to control dental caries-related pathogens. Having a good understanding of the mechanism of action of AVCO is very important in the development of an efficient treatment against dental caries-related pathogens. With an increase in the prevalence of resistance issues and a high number of dental caries cases around the globe, a therapy utilizing AVCO is becoming a more interesting option. However, an in-depth discovery regarding the mechanism of action lies beyond the scope of this study, therefore, more information and effort needed in order to make AVCO as an option for dental caries therapy.

Despite evidence that VCO provides effective antimicrobial effects against a relatively broad spectrum of microorganisms, the current finding showed that all tested dental caries-related pathogen is resistance towards VCO. Nevertheless, the justification of resistance remains to be determined. However, the antimicrobial effect of AVCO against oral pathogens associated with dental caries has been determined to be very effective against tested pathogens. The inhibition effect of AVCO shows high sensitivity against L. casei followed by C. albicans and S. mutans. AVCO was also found to have relatively rapid killing effect where most of the tested organism was killed at 8 hours point of time. Therefore, AVCO might be applied as one of the novel antimicrobial agent to arrest dental caries issues.

\section{ACKNOWLEDGMENT}

The authors are grateful to Dr. Kamariah Long for her contribution. This study was supported by the Fundamental Research Grant Scheme (FRGS) and Research Acculturation Grant Scheme (RAGS), the 
International Islamic University Malaysia, and the Malaysian Ministry of Higher Education.

\section{REFERENCES}

[1] W.J. Loesche, "Microbiology of dental decay and periodontal disease," Medical Microbiology, pp. 1-20, December 1996.

[2] W.J. Loesche, "Role of Streptococcus mutans in human dental decay," Microbiological Reviews, pp. 353-380, 1986.

[3] M. Falsetta, H. Koo, H. "Beyond mucosal infection: A role for C. albicans-Streptococcal interactions in the pathogenesis of dental caries," Current Oral Health Reports, pp. 86-93, 2014.

[4] J.D.B. Featherstone, "Prevention and reversal of dental caries: role of low level fluoride," Community Dentistry and Oral Epidemiology, pp. 31-40, 1999.

[5] J.D.B. Featherstone, "Remineralization, the natural caries repair process: The need for new approaches," Advances in Dental Research, 2009.

[6] D. Rozkiewicz, et al., "Prevalence rate and antibiotic susceptibility of oral viridans group streptococci (VGS) in healthy children population", Advances in Medical Sciences, vol. 51(Suppl 1), pp. 191-195, January 2006.

[7] J.L. Konan, R. Bourdeix, M.L. George, Regeneration guidelines: coconut. In: M.E. Dulloo, I. Thormann, M.A. Jorge, J. Hanson, eds. Crop specific regeneration guidelines. Rome, Italy: CGIAR System-wide Genetic Resource Program, 2008, pp. 10.

[8] J.J. Kabara, "Antimicrobial agents derived from fatty acids," Journal of the American Oil Chemists' Society, 1984, pp. 397403.

[9] E.B.C. Lima, et al., "Cocos nucifera (L.) (Arecaceae): A phytochemical and pharmacological review," Brazilian Journal of Medical and Biological Research, vol. 48(11), pp.953-964, 2015.
[10] T.S.T. Mansor, et al., "Physicochemical properties of virgin coconut oil extracted from different processing methods," International Food Research Journal, vol. 19(3), pp. 837-845, 2012.

[11] M.D. Mandal, S. Mandal, "Coconut (Cocos nucifera L.: Arecaceae): In health promotion and disease prevention," Asian Pacific Journal of Tropical Medicine, vol. 4(3), pp. 241-247, 2011.

[12] K. Soo-Peng, et al., "Enhanced virgin coconut oil (EVCO) as natural postmilking teat germicide to control environmental mastitis pathogens," pp.128-134, 2016

[13] B. Fife, The healing miracles of coconut oil, New York: Avery Publishing Group Inc., 2003.

[14] H. Mith, R. Duré, V. Delcenserie, A. Zhiri, G. Daube, A. Clinquart, "Antimicrobial activities of commercial essential oils and their components against food-borne pathogens and food spoilage bacteria," Food Science \& Nutrition, vol. 2(4), pp. 403 416, 2014.

[15] S.P. Koh, K. Long, "The antimicrobial activity of enhanced virgin coconut oil (EVCO) on growth of mastitis pathogens," Malaysian Journal of Microbiology, pp. 112-118, 2017.

[16] Society for General Microbiology. (2012, September 2) Coconut oil could combat tooth decay. Available: www.sciencedaily.com/releases/2012/09/120902222459.htm.

[17] F.C. Peedikayil, et al., "Comparison of antibacterial efficacy of coconut oil and chlorhexidine on Streptococcus mutans: An in vivo study," Journal of International Society of Preventive \& Community Dentistry, vol. 6(5), pp. 447-452, 2016.

[18] P. Kumar, N. Manjunatjh, M. Basil, K. Bhat, V. Joshi, M. Shetty, "A comparative evaluation of the effect of virgin coconut oil and chlorhexidine mouthwash on periodontal pathogens - An invitro microbial study," International Journal of Current Research, pp. 48062-48067, 2017. 